\title{
Genetic Diversity Assessment for Horticultural, Fruit Characters, Yield and Quality Traits among Jackfruits Genotypes
}

\author{
Atul Yadav*, Sanjay Pathak and Vimlesh Kumar \\ FASAI, Rama University, Department of Fruit Science, \\ Department of Horticulture, Acharya Narendra Deva University of Agriculture and \\ Technology, Kumarganj Ayodhya, India \\ *Corresponding author
}

\section{A B S T R A C T}

\section{Keywords}

Jackfruit, Genetic variability, Fruit characters and quality traits

Article Info

Accepted:

26 January 2021

Available Online:

10 February 2021
The present investigation was conducted with aim to know the genetic variability among the genotypes for quantitative, fruit characters and yield traits. The trials were conducted during two consecutive years and the pooled analysis of data carried out. The present investigation revealed that the analysis of variance showed that mean of squares significantly differs for all the traits due to treatments during both the years and in pooled analysis. The study further indicated that the high GCV and PCV values obtained for characters viz., number of fruits per plant, fruit weight, fruit yield per plant, fruit width, fruit length, average flake weight with seeds and number of flakes per fruit during both the years and in pooled analysis. High heritability coupled with high genetic advance was recorded for number of fruits per plant, fruit weight, fruit yield per plant, fruit length, fruit width, fruit maturity, fruit rind thickness, average flake weight with seed, number of flakes per fruit during both the years and In pooled analysis. which indicated the importance of additive gene action for the inheritance of these traits, and further improvement could be brought by phenotypic selection.

\section{Introduction}

Jackfruit tree is a multipurpose species providing food, timber, fuel, fodder, medicinal and industrial products. The trees have a significant role in the preservation of the environment, very effective in the amelioration of soils and prevention of soil erosion (Reddy et al., 2004). Jackfruit is categorized as commercial fruit but it is hardly 
cultivated in regular plantation and is commonly found in backyards of the houses. It is a tropical evergreen tree and native to India. It is widely cultivated in Malaysia, Myanmar, Bangladesh, Sri Lanka, Brazil, West Indies, Pakistan and other tropical countries. Jackfruit is the largest edible fruit in the world and according to Shree Padre (2012) a jackfruit harvested from Panruti region of Tamil Nadu weigh, as high as $81 \mathrm{~kg}$. It belongs to the Natural Order Rosales and the botanical family Moraceae.

Jackfruit is commercially grown in over 32 countries of the world and its cultivation is mainly confined to South- East Asia. Apart from India, it is grown in China, Indonesia, Malaysia, Myanmar, Thailand, Vietnam, The Philippines and Papua New Guinea.

India is the second largest producer of jackfruit in the world with an annual production of 1.83 million tones from 0.16 million hectares (Anonymous, 2017).

In India, it has wide distribution in both South and North Eastern parts. South Indian states of Kerala, Karnataka, Andhra Pradesh, Tamil $\mathrm{Nadu}$; in Eastern parts of India, Assam, Tripura; Northern parts of India, Bihar, Uttar Pradesh and the foot hills of Himalaya are the important pockets of jackfruit growing regions. In India jackfruit is popularly known as poor mane"s fruit owing to low cost and high taste of the fruit.

Evaluation of germplasm is the basic tool for identification of important genotypes. The great extent of natural variation available for various characters among the genotypes suggests good scope for improvement in economic traits. Large variability ensures better chance of producing new forms.

Variability parameters like genotypic and phenotypic coefficient of variations, heritability and genetic advance, and degree of association between the various characters and direct effect of yield contributing characters on total yield, is of paramount significance in formulating an appropriate breeding strategy aimed at exploiting the inherent variability of the original population. Phenotypic variability changes under different environmental conditions, while genetic variability remains unchanged and more useful to a plant breeder for exploitation in selection or hybridization.

\section{Materials and Methods}

The Acharya Narendra Deva University of Agriculture \& Technology where experiments was carried out is geographically located at $26.47^{\circ} \mathrm{N}$ latitude, $82.12^{\circ} \mathrm{E}$ longitude and at altitude of 113.0 meter from mean sea level in Ayodhya district of Uttar Pradesh, India.

\section{Experimental materials}

The experiment was carried out at Main Experimental Station (MES) Horticulture and Post-Harvest Technology Lab, College of horticulture \& Forestry, A.N.D.U.A. \& T, Kumarganj, Ayodhya. The experiment was conducted in Randomized Block Design (RBD).

\section{Experimental detail}

The investigation comprised of three sets of experiments. The materials used and method followed in each set of experiment is described below.

\section{Experiment No.1}

Studies on fruit characteristics and yield of jackfruit genotypes

Replication: 3

Design: Randomized Block Design (RBD) 
Number of genotypes: 13

Genotypes of jackfruit

$\mathrm{NJ}-1$

$\mathrm{NJ}-2$

$\mathrm{NJ}-4$

$\mathrm{NJ}-5$

$\mathrm{NJ}-6$

$\mathrm{NJ}-7$

$\mathrm{NJ}-8$

NJ-9

$\mathrm{NJ}-10$

$\mathrm{NJ}-11$

$\mathrm{NJ}-12$

$\mathrm{NJ}-14$

$\mathrm{NJ}-15$

\section{Observation recorded}

\section{Physical-characters}

\section{Observations recorded}

No. of fruits per plant

Fruit weight in $(\mathrm{kg})$

Fruit yield per plant $(\mathrm{kg})$

Fruit Length $(\mathrm{cm})$

Fruit width $(\mathrm{cm})$

Days to Fruit maturity

Fruit rind thickness $(\mathrm{cm})$

Av. flake weight with seed (g)

No. of flakes per fruit

Flake length $(\mathrm{cm})$

Flake width $(\mathrm{cm})$

Actual recovery of edible portion for table purpose (\%)

Actual recovery edible for Vegetable purpose (\%)

\section{Biochemical characters}

T.S.S. $\left({ }^{\circ}\right.$ Brix)

Acidity (\%)

Ascorbic acid content (mg/100g pulp)

Reducing sugar (\%)

Non reducing sugar $(\%)$

Total sugar (\%)

\section{Results and Discussion}

The data recorded on nineteen characters for thirteen genotypes from the experiment were subjected to analysis of variance (Table 1).

Mean sum of squares due to genotypes were highly significant for all nineteen characters during both the years and pooled analysis, indicating that there are significant differences among genotypes with respect to the characters under study.

The present findings are in accordance as reported by results of Hamrick et al., (1992) and Azad et al., (2007). The estimates of genotypic and phenotypic coefficients of variation for nineteen characters of jackfruit genotypes had been presented in Table 2 . The estimates of phenotypic coefficients of variations $(\mathrm{PCV})$ were higher than genotypic coefficients of variations (GCV) for all the characters.

The highest phenotypic as well as genotypic coefficients of variation were observed in case of number of fruits per plant, fruit weight, fruit yield per plant, fruit length, fruit width, fruit maturity, average flake weight with seed and number of flakes per fruit during both the years and in pooled analysis.

The estimates of moderate PCV as well as GCV were observed for fruit rind thickness, flake length, flake width, total soluble solids, ascorbic acid content, reducing sugars, nonreducing sugar and total sugars during both the years and in pooled analysis.

While, actual recovery of edible vegetable showed moderate phenotypic of coefficient of variation during $Y_{2}$ and in pooled analysis and it also showed moderate GCV during $\mathrm{Y}_{2}$.

The low PCV as well as GCV were observed for actual recovery of edible ripe and acidity content during both the years and in pooled analysis. 
Table.1 Analysis of variance for nineteen quantitative and quality characters in jackfruit during $\mathrm{Y}_{1}, \mathrm{Y}_{2}$ and over the season

\begin{tabular}{|c|c|c|c|c|c|c|c|c|c|c|}
\hline \multirow[t]{4}{*}{ S.N. } & \multirow[t]{2}{*}{ Sources of variation } & \multicolumn{9}{|c|}{ Mean squares } \\
\hline & & \multicolumn{3}{|c|}{ Replication } & \multicolumn{3}{|c|}{ Treatments } & \multicolumn{3}{|c|}{ Error } \\
\hline & \multirow[t]{2}{*}{ d.f. } & \multicolumn{3}{|c|}{2} & \multicolumn{3}{|c|}{12} & \multicolumn{3}{|c|}{24} \\
\hline & & $Y_{1}$ & $Y_{2}$ & Pooled & $Y_{1}$ & $\mathbf{Y}_{2}$ & Pooled & $\mathbf{Y}_{1}$ & $\mathbf{Y}_{2}$ & Pooled \\
\hline 1 & No. of fruits per plant & 1.03 & 2.38 & 0.94 & $1663.13 * *$ & $1845.90 * *$ & $1633.76^{* *}$ & 3.30 & 4.80 & 2.50 \\
\hline 2 & Fruit weight (kg) & 0.01 & 0.01 & 0.00 & $73.68 * *$ & $78.64 * *$ & $76.16^{* *}$ & 0.02 & 0.02 & 0.01 \\
\hline 3 & Fruit yield per plant (kg) & 267.71 & 107.64 & 176.18 & $289386.49 * *$ & $379762.35 * *$ & $326969.47 * *$ & 344.84 & 351.82 & 212.26 \\
\hline 4 & Fruit Length $(\mathrm{cm})$ & 0.10 & 0.11 & 0.06 & $252.11 * *$ & $276.40 * *$ & $264.07 * *$ & 0.44 & 0.81 & 0.20 \\
\hline 5 & Fruit width $(\mathrm{cm})$ & 0.32 & 0.79 & 0.15 & $173.11 * *$ & $190.08 * *$ & $181.47 * *$ & 0.19 & 0.42 & 0.19 \\
\hline 6 & Fruit maturity & 1.53 & 26.93 & 4.16 & $3086.41 * *$ & $3135.39 * *$ & $3056.80 * *$ & 12.60 & 22.33 & 6.91 \\
\hline 7 & Fruit rind thickness $(\mathrm{cm})$ & 0.00 & 0.00 & 0.00 & $0.12 * *$ & $0.13^{* *}$ & $0.12 * *$ & 0.00 & 0.00 & 0.00 \\
\hline 8 & Av. flake wt. with seed (g) & 0.00 & 0.09 & 0.03 & $41.72 * *$ & $44.62 * *$ & $43.14 * *$ & 0.08 & 0.14 & 0.04 \\
\hline 9 & No. of flakes per fruit & 47.22 & 4.33 & 12.71 & $20845.42 * *$ & $22620.91 * *$ & $21740.00 * *$ & 47.31 & 30.22 & 15.95 \\
\hline 10 & Flake length $(\mathrm{cm})$ & 0.01 & 0.00 & 0.00 & $0.75 * *$ & $0.79 * *$ & $0.77 * *$ & 0.00 & 0.01 & 0.00 \\
\hline 11 & Flake width $(\mathrm{cm})$ & 0.01 & 0.00 & 0.00 & $0.29 * *$ & $0.33 * *$ & $0.31 * *$ & 0.00 & 0.01 & 0.00 \\
\hline 12 & Actual recovery edible ripe $(\%)$ & 0.36 & 1.20 & 0.30 & $21.47 * *$ & $24.06 * *$ & $22.75 * *$ & 0.99 & 0.99 & 0.55 \\
\hline 13 & Actual recovery edible Veg. (\%) & 0.11 & 5.50 & 1.24 & $123.00 * *$ & $140.16^{* *}$ & $131.21 * *$ & 1.49 & 2.60 & 1.04 \\
\hline 14 & T.S.S. $\left({ }^{\circ}\right.$ Brix $)$ & 0.03 & 0.56 & 0.16 & $20.25 * *$ & $20.73 * *$ & $20.49 * *$ & 0.09 & 0.21 & 0.07 \\
\hline 15 & Acidity $(\%)$ & 0.00 & 0.00 & 0.00 & $0.00 * *$ & $0.00 * *$ & $0.00 * *$ & 0.00 & 0.00 & 0.00 \\
\hline 16 & Ascorbic acid content (mg/100g pulp) & 0.37 & 0.18 & 0.26 & $26.10 * *$ & $27.07 * *$ & $26.57 * *$ & 0.24 & 0.23 & 0.14 \\
\hline 17 & Reducing sugar (\%) & 0.00 & 0.22 & 0.04 & $14.67 * *$ & $15.25^{* *}$ & $14.96 * *$ & 0.08 & 0.11 & 0.05 \\
\hline 18 & Non reducing sugar $(\%)$ & 0.00 & 0.01 & 0.00 & $0.37 * *$ & $0.38^{* *}$ & $0.37 * *$ & 0.01 & 0.01 & 0.00 \\
\hline 19 & Total sugar $(\%)$ & 0.15 & 0.02 & 0.06 & $13.72 * *$ & $15.55 * *$ & $14.52 * *$ & 0.07 & 0.06 & 0.03 \\
\hline
\end{tabular}

*,** Significant at 5 per cent and 1 per cent probability levels 
Table.2 Genetic parameters for nineteen characters in jackfruit during $\mathrm{Y}_{1}, \mathrm{Y}_{2}$ and over the season

\begin{tabular}{|c|c|c|c|c|c|c|c|c|c|c|c|c|c|}
\hline \multirow[t]{2}{*}{ S.No. } & \multirow[t]{2}{*}{ Components Traits } & \multicolumn{3}{|c|}{ PCV } & \multicolumn{3}{|c|}{ GCV } & \multicolumn{3}{|c|}{$h^{2}$ (Broad Sense) } & \multicolumn{3}{|c|}{$\begin{array}{c}\text { Genetic Adv as \% of } \\
\text { Mean at } 5 \%\end{array}$} \\
\hline & & $\mathbf{Y}_{1}$ & $\mathbf{Y}_{2}$ & pooled & $\mathbf{Y}_{1}$ & $\mathbf{Y}_{2}$ & pooled & $Y_{1}$ & $\mathbf{Y}_{2}$ & pooled & $\mathbf{Y}_{1}$ & $\mathbf{Y}_{2}$ & Pooled \\
\hline 1 & No. of fruits per plant & 32.22 & 32.69 & 31.31 & 32.12 & 32.56 & 31.24 & 99.41 & 99.22 & 99.54 & 65.97 & 66.82 & 64.20 \\
\hline 2 & Fruit weight (kg) & 66.63 & 66.07 & 66.39 & 66.61 & 66.07 & 66.34 & 99.91 & 99.94 & 99.96 & 137.14 & 136.03 & 136.71 \\
\hline 3 & Fruit yield per plant $(\mathrm{kg})$ & 63.43 & 62.94 & 62.57 & 63.32 & 62.85 & 62.51 & 99.64 & 99.72 & 99.81 & 130.21 & 129.30 & 128.64 \\
\hline 4 & Fruit Length (cm) & 31.09 & 31.33 & 31.16 & 31.01 & 31.19 & 31.12 & 99.48 & 99.12 & 99.77 & 63.70 & 63.97 & 64.05 \\
\hline 5 & Fruit width $(\mathrm{cm})$ & 33.89 & 34.06 & 33.95 & 33.84 & 33.96 & 33.91 & 99.67 & 99.35 & 99.68 & 69.58 & 69.71 & 69.73 \\
\hline 6 & Fruit maturity & 22.07 & 21.71 & 21.63 & 21.94 & 21.48 & 21.55 & 98.78 & 97.89 & 99.33 & 44.91 & 43.79 & 44.25 \\
\hline 7 & Fruit rind thickness $(\mathrm{cm})$ & 18.28 & 18.42 & 18.31 & 18.09 & 18.24 & 18.10 & 98.49 & 97.28 & 98.55 & 37.09 & 36.91 & 37.17 \\
\hline 8 & Av. flake wt. with seed (g) & 30.75 & 30.63 & 30.64 & 30.65 & 30.49 & 30.59 & 99.42 & 99.04 & 99.69 & 62.98 & 62.50 & 62.92 \\
\hline 9 & No. of flakes per fruit & 36.83 & 36.85 & 36.81 & 36.70 & 36.77 & 36.77 & 99.32 & 99.60 & 99.78 & 75.35 & 75.60 & 75.67 \\
\hline 10 & Flake length $(\mathrm{cm})$ & 12.67 & 12.64 & 12.56 & 12.57 & 12.37 & 12.49 & 98.50 & 95.98 & 98.61 & 25.71 & 24.98 & 25.52 \\
\hline 11 & Flake width $(\mathrm{cm})$ & 12.59 & 13.01 & 12.70 & 12.37 & 12.71 & 12.56 & 96.24 & 95.15 & 97.50 & 24.96 & 25.50 & 25.50 \\
\hline 12 & Actual recovery edible ripe $(\%)$ & 7.15 & 7.24 & 7.07 & 6.68 & 6.82 & 6.82 & 87.33 & 88.55 & 93.04 & 12.85 & 13.21 & 13.55 \\
\hline 13 & Actual recovery edible veg.(\%) & 9.99 & 10.32 & 10.08 & 9.81 & 10.04 & 9.96 & 96.45 & 94.63 & 97.65 & 19.85 & 20.12 & 20.27 \\
\hline 14 & T.S.S. $\left({ }^{\circ}\right.$ Brix $)$ & 14.32 & 14.38 & 14.29 & 14.23 & 14.16 & 14.22 & 98.73 & 96.96 & 99.02 & 29.13 & 28.72 & 29.15 \\
\hline 15 & Acidity $(\%)$ & 8.25 & 8.11 & 8.16 & 7.60 & 7.91 & 8.16 & 100.00 & 90.00 & 100.00 & 16.99 & 15.03 & 16.82 \\
\hline 16 & Ascorbic acid content (mg/100g pulp) & 15.07 & 15.12 & 15.04 & 14.86 & 14.94 & 14.93 & 97.32 & 97.51 & 98.47 & 30.21 & 30.38 & 30.51 \\
\hline 17 & Reducing sugar (\%) & 18.44 & 18.60 & 18.47 & 18.31 & 18.40 & 18.38 & 98.44 & 97.89 & 98.97 & 37.40 & 37.50 & 37.67 \\
\hline 18 & Non reducing sugar $(\%)$ & 12.14 & 12.08 & 12.01 & 11.76 & 11.80 & 11.82 & 94.03 & 95.52 & 97.07 & 23.51 & 23.76 & 24.01 \\
\hline 19 & Total sugar $(\%)$ & 14.49 & 15.05 & 14.69 & 14.38 & 14.96 & 14.64 & 98.53 & 98.89 & 99.34 & 29.41 & 30.65 & 30.07 \\
\hline
\end{tabular}

*** Significant at 5 per cent and 1 per cent probability levels 
However, actual recovery content of fruit at vegetable stage showed low estimates of PCV in $\mathrm{Y}_{1}$ and $\mathrm{GCV}$ in $\mathrm{Y}_{1}$ and in pooled analysis. The values for ECV were low for almost characters during both the years and in pooled analysis. The present study corroborated with the findings of Ramakrishna et al., (2006) and Simon et al., (2007).

\section{Heritability and genetic advance}

Estimates of heritability (in broad sense) and genetic advance (in per cent of mean) for different characters has been presented in Table 2. The heritability in broad sense (\%) ranged from $87.33,88.55$ and 93.04 in case of length of pod (cm) during 2017-18 \& 2018-19 and in pooled analysis, respectively to 100 per cent in $\mathrm{Y}_{1}$ and in pooled analysis in case of acidity content, while during $\mathrm{Y}_{2}$, fruit weight recorded maximum heritability $99.94 \%$.

High estimates of heritability (>80) were recorded for all the characters during both the years and in pooled analysis.

High heritability coupled with high genetic advance was observed for number of fruits per plant, fruit weight, fruit yield per plant, fruit length, fruit width, fruit maturity, fruit rind thickness, average flake weight with seed, number of flakes per fruit, ascorbic acid content and reducing sugars during both the years and in pooled analysis.

While, total sugar content was recorded high estimates heritability along with high genetic advance during $\mathrm{Y}_{2}$ and in pooled analysis.

However, high heritability coupled with moderate genetic advance was observed for flake length, flake width, total soluble solids and non-reducing sugar during both the years and in pooled analysis.

Whereas, actual recovery of fruit at vegetable stage was recorded high estimates of heritability along with moderate estimates of genetic advance during $\mathrm{Y}_{2}$ and in pooled analysis.

Total sugar content showed high heritability coupled with moderate genetic advance during first of experimentation.

However, high estimates of heritability coupled with low genetic advance were recorded for actual recovery of fruit at ripe stage during both the years and in pooled analysis the present findings supported by the study of Sharma et al., (2005).

\section{References}

Anonymous. (2017). Jackfruit improvement in the Asia Pacific Region a status report. Asia Pacific Association of Agricultural Research Institutions, Bangkok, Thailand, p.182.

Azad, A. K.; Jones, J. G. and Haq, N. (2007).Assessing morphological and isozyme variation of jackfruit (Artocarpus heterophyllus Lam.) in Bangladesh. Agroforestry Syst., 71:109-125.

Hamrick, J.L.; Godt, M.J.W. and Sherman, S.L.B. (1992).Factors influencing levels of genetic diversity in woody plant species. New Fores., 6:95-124.

Reddy, B.M.C., Prakash Patil, S., Shashikumar, S. and Govindaraju. (2004). Studies on physico-chemical characteristics of jackfruit clones of south Karnataka. Karnataka J. Agri. Sci., 17(2): 279-282

Ramakrishna, M.; Madhumathi, C.; Sadarun, N. and Purushotham, K. (2006). Performance of different varieties of jackfruit (Artocarpus heterophyllus Lam.) in southern zone of Andhra Pradesh. Proceedings of the National symposium on production, utilization 
and export of underutilized fruits with commercial potentialities, Kalyani, West Bengal, India, p. 42-44.

Padre,Shree. (2012) "jackfruit Businss" Civil Socity Online. http://www. Civil society online. Com /page/detail s.aspx?146

Simon, L.; Shyamalamma, S. and Narayanaswamy, P. (2007).
Morphological and molecular analysis of genetic diversity in jackfruit. $J$. Hort. Sci. Biotech., 82(5):764-768.

Simon, L.; Shyamalamma, S. and Narayanaswamy, P. (2007). Morphological and molecular analysis of genetic diversity in jackfruit. $J$. Hort. Sci. Biotech., 82(5):764-768.

\section{How to cite this article:}

Atul Yadav, Sanjay Pathak and Vimlesh Kumar. 2021. Genetic Diversity Assessment for Horticultural, Fruit Characters, Yield and Quality Traits among Jackfruits Genotypes. Int.J.Curr.Microbiol.App.Sci. 10(02): 3333-3339. doi: https://doi.org/10.20546/ijcmas.2021.1002.366 